\title{
Heritage Landscapes: Rethinking the Canadian Experience 1
}

\author{
by
}

Peter J. Dooling²

\begin{abstract}
One of Canada's important anniversaries will be the centennial of the National Parks of Canada in 1985. This provides a rare opportunity to recognize, review, promote and improve Canada's national and provincial heritage in all its natural and historic forms. With this in mind Canada commissioned a program of Caucuses leading to a Canadian Assembly on National Parks and other protected areas in Banff, 1985. The Assembly and the efforts to bring together concerned citizens to provide a framework for the review of natural and cultural resources management problems in Canada are briefly discussed. Two heritage conservation issues are reviewed in some detail.
\end{abstract}

\section{Résumé}

Un des centenaires les plus importants sera celui des Parcs nationaux du Canada en 1985. Ceci nous fourait l'occasion de reconnaître, revoir, promouvoir et améliorer l'héritage provincial et national au Canada sous toutes ses formes qu'elles soient naturelles ou culturelles. En gardant ceci à l'esprit, le Canada a parrainé un programme de rencontres lequel a mené à la création d'une réunion canadienne sur les parcs nationaux et autres régions protégées, à Banff en 1985, la réunion et les efforts déployés par des citoyens concernés afin de fournir un cadre de travail pour réviser la gestion des ressources naturelles et culturelles sont discutés. Deux cas de conservation du patrimoine sont revus en détail.
One of Canada's most important heritage anniversaries will be the Centennial of our National Park System, 1985. This provides a rare opportunity to recognize, review, promote and improve our national and provincial heritage in all its natural and historic forms. With this in mind Canada commissioned in December, 1983 a program of Caucuses in 1984-85 leading to a Canadian Assembly on Parks and other Protected Areas in Banff, September 4-8th, 1985. This conference is expected to have a strong influence on the future direction for heritage conservation areas in Canada by helping public organizations reassess their goals and if necessary, realign or even replace them to suit changes in society's interests and values. The program of the Caucuses, which is formative to the Canadian Assembly, called for establishing seven Regional Caucuses throughout Canada: two Northern Territory caucuses, Atlantic region, Quebec, Ontario, Prairie region and British Columbia. The public consultative process of the Caucuses is to occur to the end of this year throughout Canada, the methods to be used being at the discretion of each Caucus.

\footnotetext{
1Paper prepared for a joint meeting of the SAF/CIF Working Group on Recreation, Forest Landscape \& Tourism, International Forest Congress, Quebec City, August 7 th, 1984

2Pet er J. Dooling, Associate Professor, Park and Recreation Resources, Faculty of Forestry, University of British Columbia, Vancouver, British Columbia, V6T
} 1W5. Also, Chairman, British Columbia Caucus, Heritage for Tomorrow.
The British Columbia Caucus was commissioned in February, 1984 with an 11-member steering committee. The committee consists of six regional and five members at-large representing natural resource conservation, outdoor recreation, and related tourism interests from throughout British Columbia. The term "Caucus" refers to a wide ranging public consultation process for recognition of heritage conservation issues, policy concerns and programs needed to deal with the issues identified.

The goals of the British Columbia Caucus are two: First, to prepare through research and public consultation, a provincial paper on natural and historic heritage conservation issues, policy concerns and recommendations. In particular, issues and subjects forming key elements of our parks heritage (national and provincial) and equivalent reserves in British Columbia are being identified, studied, and will be reported upon; and Secondly, to prepare a Recommended List of Heritage Conservation Candidate Areas, those areas considered to be of critical importance to the establishment of a system of protected heritage areas that could be designated as parks or equivalent reserves. Priority ranking of areas, provincial and national scales of heritage significance are, where possible, to be included in the review.

Although there is no statutory duty for either the federal or provincial governments to consult with the public, a public 
consultative process was commenced with the Symposium on Parks in British Columbia, February 1984, on the campus of the University of British Columbia. Some 350 participants from throughout the province with several other provinces represented discussed 23 invited papers. Since then, six subregional caucus steering committees have formed to conduct public workshops to discuss and report upon in greater depth the heritage conservation, park and related area matters most pertinent to their regions and to contribute innovative ideas for better strategies for establishing and managing protected landscapes in the rural lands of British Columbia.

The public throughout the province is being given a meaningful opportunity to make known its views and concerns. The public consultative programme of the British Columbia Caucus has conducted 12 public workshops across the province - an intensive effort by the citizens of British Columbia all on a voluntary basis. The research programme of the Caucus is geared to provide a broad information base on heritage conservation as well as to systematically and comprehensively treat selected problems.

In this paper I focus on two issues. The first, pertaining to problems in the process of national park acquisition in Canada, is the issue of the federal landholding requirement. ${ }^{3}$ The second, pertaining to problems of nature protection and recreation-tourism provision, is the issue of legislation of wilderness in the national parks of Canada ${ }^{4}$. Among readers of the Forestry Chronicle there is substantial experience. I seek your comments and wish to learn about experiences elsewhere.

\section{Problems in the National Park Acquisition Process}

\section{The Present Federal Landholding Scheme}

The constitutional division of powers in Canada necessitate in southern Canada active involvement of both the provincial and federal governments in the process of establishing a national park; the process culminating in a federal landholding. This federal land ownership requirement is one of the most troublesome and recurrent problems in the Canadian national park acquisition process.

The definition in the National Parks Act of Public lands is such that it precludes any type of provincial or private land ownership within national park boundaries. This very restrictive definition found in the National Parks Amendment Act can be traced to the Dominion Forest Reserves Act of 1906 and the Dominion Forest Reserves and Parks Act of 1911 which expressly excluded from the provisions of those Acts any lands other than those vested in the federal crown. As a result, the onus is on the province to negotiate for or expropriate lands and interests in land to meet the schedule of land transfer to the federal government as set out in the park agreement. The loss of provincial jurisdiction, the problems of negotiating purchase or expropriation of land rights, the high costs of negotiated purchase or expropriation of land, the repurchase of extractive industry rights or re-allocation of these resource rights elsewhere, political pressure and pro-

\footnotetext{
${ }^{3}$ The author wishes to ackowledge in this section heavy reliance on the article written by Rosemary E. Nation, "The Acquisition of National Parkland: A challenge for the Future". Dalhousie Law Journal Vol. 7 (3) October 1983. p.260-296. ${ }^{4} \mathrm{Many}$ of the ideas expressed in this section were taken from P. A. Thompson, "Legislation of Wilderness in National Parks: Options for Consultation with the Public". Mimeographed Paper. National Parks Branch, January, 1984. 23 p.
}

test from land or interest holders within the proposed park area all constitute disincentive for provincial involvement in national parkland agreements. These disincentives have influenced national park creation, illustrated dramatically when one realizes that (1) with removal of the northern territorial national park reserves $91 \%$ of the national park area existing today was established before 1930, primarily out of Dominion Forest Reserves; and (2) from 1930 to present, only two western parks, Pacific Rim National Park (1971) on Vancouver Island, and Grasslands National Park (1982) in Saskatchewan, were established.

If one accepts that the aim of the Canadian National Park system is to include within its parks natural areas that are of Canadian significance and are worthy of protection, then it is clear that our system is, 100 years later, less than halfway toward its objective. The problems arising from the necessity of federal government title and control and their braking effect on national park negotiations today call for considering abandonment of the federal land ownership requirement.

\section{Cooperative Landholding Arrangements - A Path for the Future?}

Cooperative landholding, involving private, provincial and federal ownership possibilities and administered by a federalprovincial board, had been proposed as a solution to the problems caused by the present federal landholding requirement.

The cooperative landholding solution would entail (1) some sacrifice of the ease of the federal control, and (2) some relaxation of the concept of park as an area free of residents and all extractive uses. The solution is said to be justifiable on the premise that this is the only way that the national park system can expand enough to be totally representative of Canada's important landforms. The solution would involve both federal and provincial legislation and joint arrangements: the provincial government would control industry and privately owned land within the park through use of a system of park permits and zoning regulations, while the federal government would control lands held in its name and would formulate policy jointly with the provincial government. The solution's immediate objective would be to freeze settlement and development within the park. Administration of the land agreement would be undertaken with a gradual return to wilderness as its ideal, long-term goal, or to a type of park management that would allow a cultural landscape to remain where the portrayal of the relationship of man and nature is approved. The "new approach" is advocated only for new, not existing national parks, and is based on the supposition that some preservation is superior to none at all.

Proponents of this new approach offer several rather convincing arguments: (1) problems related to land expropriation and people displacement can be avoided, as neither need not occur; (2) initial land assembly costs and local citizen protest can be reduced; (3) lesser political and monetary expenses, at least initially, and so absolute loss of provincial jurisdiction could alleviate provincial reluctance to establish parks; (4) the ability of citizens to retain their land and remain in the superimposed park may make them more amenable and available to participate and give advice in eventual park planning; and (5) realization that the federal government alone, through Parks Canada, no longer has a monopoly providing strict conservation areas nor is it consistent in its approach therein. Increasingly in Canada, provincial governments 
present legislation for wilderness areas and ecological reserves, both which have less emphasis on public use than National Parks in southern Canada. Further, it seems somewhat ironic - certainly inconsistent - that Parks Canada regulates and leases land within national park boundaries to thousands of residents in the western national park townsites, then deems it necessary not only to hold all land in newly acquired parks, but also to attempt to remove the residents.

The two apparent major criticisms of this cooperative landholding approach are that (1) only the federal government can withstand development pressures; and (2) problems of intergovernmental coordination may be difficult. In response to the first criticism, the preservation record of federal government control does not necessarily inspire awe, nor is it clear that provincial government control would necessarily result in a poorer job being done. The answer is not easily found. The second criticism to the "new approach" seems to arise from concern over the provinces having substantial regulatory and ownership control: regulation of private landholdings and persons within the park, and ownership and regulation of provincial lands within the park. The answer to the criticism is illusive. Suffice to say that it is not clear why the provinces would not be capable of extending methods of control to residents and industry within a cooperatively administered national park area.

At present, a type of cooperative landholding system is in place during the interim management phase that occurs prior to the final transfer of land and resource rights. As the time of this stage increases, it would require only a small mental jump to the legislative and policy changes necessary to allow this but with a much improved structure. The present system, with its defects and political realities, must be revised if it is to allow sufficient growth. A multi-level governmental approach that accommodates constitutional reality seems apparent.

The greenline park concept involves a multi-level governmental approach to nationally significant resources in the United States. As I understand it, the "greenline park" involves a specially designated region under a mixed pattern of public and private ownership. Public land ownership was to be restricted to very selected areas; elsewhere within the region; the managing authority would acquire scenic or conservation easements. The "greenline park" concept seems also very close in concept to the British National Parks System.

From readers of the Forestry Chronicle, I'd like to hear and learn more of your experience with cooperative land use planning ventures; they no doubt would be more difficult entities to manage. To create new parks with greenline characteristics, and to make them work, what must be the effective land use controls? Has any tough pragmatic evaluation of the greenline experiments been undertaken? What is the proper federal interest in provincial land ownership and natural resource regulation? What is the proper federal and provincial interest in private land use regulation? What is the current of the times use for land use planning? We grope for the formula for success.

\section{Problems of Nature Protection and Recreation-Tourism Provision}

Problems are being experienced in balancing park protection and tourist use. Loose definition and wide application of the terms "park" and "tourism" allow for an almost infinite number of actual relationships, conflicting, coexisting, and symbiotic, between the two. In this vast amalgam of parktourism relationships, attention naturally tends to focus on unsatisfactory and problematic cases rather than successful ones. Conflict is serious where tourism of a particular type occurs in a park least suited to that type of tourism or where the demands of even an appropriate type of tourism are excessive for the park environment; these conflicts raise questions concerning objectives and scale. Conflict is most serious when park-tourism relationships involve problems both of objectives and scale.

\section{Current Strategies to Deal with Park Tourism}

As the problem of reconciling parks protection and park useage became more critical, park agencies have adopted a variety of strategies in Canada to deal with tourism growth and its impacts on park environment and visitor experience. Other strategies than the one to be discussed exist: for example, through park system expansion, through park classification, through regional planning by developing the bulk of tourist facilities outside the limits of a park and through parks management by direct and indirect approaches to regulation of visitor behavior.

The key strategy adopted in the National Parks of Canada to help mitigate park protection and useage is one of internal zoning. Parks Canada adopted zoning while preparing national park management plans in the 1960's. Advocates claim it assists in managing the tension between the use and preservation. Accordingly, most national parks are today divided into five zones affording differing levels of nature protection and recreation-tourism provision. they are: Zone I special conservation; Zone II - wilderness; Zone III - natural environment; Zone IV - outdoor recreation, and Zone V park services. Consistent with Park Canada's main objective, a bias towards nature protection is evident in the policy statement that zones IV and V". . . will occupy no more than a small proportion of lands in a national park. Moreover, in certain national parks in remote areas, no provision will be made for such zones". 5

Park zones, however, even if supported by precise definitions of objectives and activities, facilities, and management appropriate to each, remain vulnerable to pressures particularly external pressures such as growing demands for recreation/tourism and natural resource utilization. In the United States, recognition of these problems led to the introduction of a Wilderness Act (1964) and a legislatively defined and protected system of wilderness areas. In Canada national parks zones have no legislated protection, being only administrative guidelines established by and for the managing agency. For these reasons the idea of legislating wilderness areas within national parks continues to receive consideration.

\section{Legislation of Wilderness in National Parks - A Path for the Future?}

Proponents for legislating wilderness in national parks argue that the existing internal zoning system may not be strong enough to ensure long term protection of park wilderness areas. Further Parks Canada, in its consultations and negotiations for new northern national parks, has indicated to the people of the north that legislated wilderness would be an option for consideration within those parks. For these reasons,

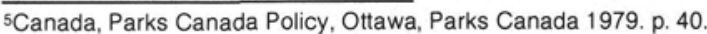


the benefits and difficulties of legislation of wilderness need to be evaluated.

Four options exist relating to the issue. These include: (1) no legislation of wilderness areas (status quo); (2) legislation of wilderness areas in national parks in the Territories (one zone, northern parks only); (3) legislation of wilderness areas in all appropriate national parks (one zone, all parks); and (4) legislation of wildnerness areas and other zones in all appropriate national parks (all zones, all parks). Which of the four options is publicly preferred is unknown. If steps are taken to legislate wilderness into the National Parks Act the following definition is suggested by Parks Canada:

"A wilderness area in a National Park is a natural area in excess of 2000 ha which is in an unaltered, wild state and which will be maintained to preserve its wilderness unaffected by man's work. A wilderness area is one where man is a visitor who does not remain."6

\section{Is the proposed definition adequate based on experience elsewhere?}

In addition to considering the options relating to the issue of whether or not there is a need for legislation of wilderness in National Parks is, if so, the further consideration of what form. Legislation to establish wilderness areas in national parks by proclamation or by regulation, which is most desirable and why? The proclamation approach is viewed as providing the greatest degree of protection for wilderness areas since proclamation would be set out in a schedule to the National Parks $A c t$, and revocation or amendments of the description could only be by amendment to the Act, a lengthy and difficult process. The regulation approach would provide greater pro-

6Thompson, P.A. Legislation of Wildnerness in National Parks: Options for Consultation with the Public. Mimeographed Paper. National Parks Branch, January, 1984 tection than is presently afforded special preservation and wilderness zones under park management plans, would not be as inflexible or alternatively would be as seen in the eyes of some, an easier means of modifying wilderness areas than the proclamation approach.

\section{Conclusion}

In closing it might be fair to suggest that Canadians do not have the same perception of scarcity, in either a land base for development or a land base for preservation, as do Americans. Wilderness preservation, because of a smaller population, large amounts of public land and a perception of still relatively large unexploited forest wealth, has scarcely raised a tremor in Canada compared with that in the United States. On the other hand, stress on land is increasingly evident throughout Canada. Increased competition for natural resources is real and non-conflict examples are: (1) Pacific Rim National Park boundaries illustrate since 1971 a classic conflict with the British Columbia forest industry; (2) Kluane National Park's 33-year gestation period illustrates a classic conflict with the mining industry; (3) Prairie Grasslands National Park's 16-year-period with the agriculture industry; (4) the proposed national park on the East Arm, Great Slave Lake demonstrates the very slow progress with respect to native claims, and (5) the abandoned Ship Harbour National Park illustrates the frustration of trying to establish large resource-based parks in settled areas.

In preparation for the Canadian Assembly, the work of the Regional Caucuses throughout Canada is evolving out of the realization that any future for heritage conservation in Canada must ultimately be decided at the public level in the broad arena of competing interests. United States experience in the legislated wilderness concept and the greenline park concept are both useful experiments for our review. Information on these selected issues would be much appreciated; comments are also welcomed.

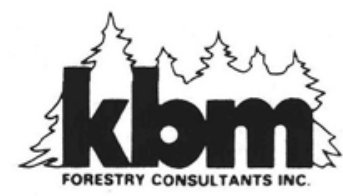

REFORESTATION EQUIPMENT

- Sales Service Parts Repair

REGENERATION \& SITE PREPARATION

- Contract Assessment Consulting

807-344-0811 telex 073-4603 